Department of Animal Breeding, Faculty of Agronomy, Mendel University of Agriculture and Forestry Brno, Brno, Czech Republic

\title{
Relationships between backfat thickness and parameters of reproduction in the Czech Large White sows (short communication)
}

\begin{abstract}
Relationships between backfat thickness and litter performance for individual parities were analyzed on performance-test data under field conditions of 8,285 Large White sows from 39 farms. Backfat thickness measured by ultrasound was corrected for a live weight of $90 \mathrm{~kg}$. Young gilts with a higher backfat thickness achieved higher litter performance and a higher number of litters. Litter size increased from the first until the fifth parity.
\end{abstract}

Key Words: sow, backfat, fertility, parity

\section{Zusammenfassung}

Titel der Arbeit: Beziehungen zwischen der Rückenspeckdicke und Reproduktionsmerkmalen bei Tschechischen Large White Sauen (Kurzmitteilung)

An 8285 Sauen der Rasse Large White, in 39 Betrieben im Feldtest eigenleistungsgeprüft, wurde der Zusammenhang zwischen der Rückenspeckdicke und Wurfleistungen in den einzelnen Lebenswürfen untersucht. Die mittels Ultraschall gemessene Speckdicke wurde auf ein Körpergewicht von $90 \mathrm{~kg}$ der Sauen korrigiert. Jungsauen mit einer größeren Rückenfettschicht erreichten bessere Wurfgrößen und höhere Wurfnummern. Die Wurfgrößen stiegen vom ersten bis zum fünften Wurf.

Schlüsselwörter: Sau, Rückenspeckdicke, Wurfleistung, Wurfnummer

\section{Introduction}

In some cases an unilateral selection for meat performance caused undesired correlative changes in other traits and resulted for example in a reduced reproduction and an increased susceptibility to unfavourable effects of some environmental factors (SIILER et al., 1980; WÄHNER et al., 2001a). TVRDON et al. (1998) observed that the fertility increased with the increasing backfat thickness. This trend was highly significant in the number of piglets born alive in the group of sows with the thickness of backfat ranging from 11.1 to $14.0 \mathrm{~mm}$. The correlation between the number of piglets born alive and the lifelong performance was $r=0.0919$. ČECHOVÁ and BUCHTA (1995) studied the development of performance and reproduction parameters within a series of generations of mother and their granddaughters and found out that the thickness of backfat decreased by $7.3 \mathrm{~mm}$ (i. e. by $37.24 \%$ ). WHITTEMORE et al. (1995) mentioned that in primiparous sows a sufficient layer of backfat was a guaranty of fertility also on the second parturition. JOHN et al. (2001) demonstrated a significant effect of backfat thickness on the litter size and the moment of the first insemination. The effect of backfat thickness on fertility was mentioned also by LEMBER (1994). Sows reach the maximum fertility (often already at the $3^{\text {rd }}$ litter) they are culled and replaced by animals with a better performance (NIBE et al., 
1995). A similar observation was mentioned also by BÖSCH et al. (1999). LUNDEHEIM and ELIASSON-SELLING (1996) concluded that it is difficult to estimate the fertility on the second and/or following parturitions only on the base of the first litter size.

The objective of this study was to evaluate the influence of back fat thickness in young sows to litter performance in the first and later litters.

\section{Material and methods}

Relationships existing among backfat thickness, rank of parturition and numbers of all, living and weaned piglets were analyses in a set of 8285 sows of the Large White breed. The total number of farms under study was 39. The analysis was performed using data about the Performance control of pigs (standard ČSN 46 6164), which were obtained from the Pig Breeders Association in Bohemia and Moravia. This study took place within the period of $1994-1997$. The thickness of backfat was measured with the apparatus Piglog 100 of Danish provenience in the course of performance testing carried out within the framework of field tests. Measurements were performed in two points at the distance of $70 \mathrm{~mm}$ from back midline. Animals that passed through these performance tests were fed ad libitum on a uniform feed mixture (TESTA). The contents of energy and lysine were $13 \mathrm{MJ} \mathrm{ME}$ and $11 \mathrm{~g}$, respectively. This test lasted for 63 days and began at the age of 12 weeks ( \pm 4 days). The size of a tested group was 6 to 12 animals per pen and each group consisted of progeny of two boars at least. The minimum floor area per sow was $0.8 \mathrm{~m}^{2}$. The average thickness of backfat (mm) was calculated on the base of two measurings and corrected to a uniform live body weight of $90 \mathrm{~kg}$.

Besides basic statistical characteristics (mean, standard deviation, variance) the analysis involved also calculations of correlation coefficients, which were approximated as linear ones. These coefficients were calculated using the unifactorial analysis of covariance where the father's effect was used as the source of variability. The analysis of individual systematic effects influencing the phenotypic variation of traits under study was performed on the base of a linear model. The following effects were used in this model: original herd, backfat thickness, lean meat percentage, average daily gain, and parity number. The Tukey-test was used for testing of differences. The analysis was performed using the statistical programme UNISTAT 4.53. (UNISTAT, 1998).

\section{Results}

Basic statistical characteristics of backfat thickness and numbers of all, born alive and weaned piglets estimated within the framework of performance control of Large White sows on the base of different ranks of parturitions are presented in Table 1 . These means enable indicate that the backfat thickness showed an increasing tendency from $10.99 \mathrm{~mm}$ at the first farrowing to $12.21 \mathrm{~mm}$ at the seventh and subsequent parturitions. The difference between the backfat thickness at the $1^{\text {st }}$ and the $7^{\text {th }}$ (and subsequent) farrowing was $1.22 \mathrm{~mm}(10,00 \%)$.

The character of these changes in measured values is linear (Fig.). The increasing backfat thickness of sows with a higher number of parturitions indicates that sows with a higher percentage of fat remain in the herd for a longer period and that they show a positive effect on the average longevity. The analysis of numbers of all, alive-born and 
weaned piglets again corroborated the fact that the fertility increased with the increasing rank of the litter. The obtained results indicate that the lowest number of all piglets (10.5) was in the first litter while the highest one (12.09) in the fifth litter. A similar trend was observed also in numbers of piglets alive-born, viz. 9.81 vs. 11.05 on the first and the fifth parturition, resp.; as far as the weaned piglets were concerned, their lowest and highest numbers were recorded in the $1^{\text {st }}$ and the $3^{\text {rd }}$ litter: 8.77 vs. 9.65, respectively. In this case it is necessary to consider a great effect of exogenous factors on the rearing of piglets.

\section{Table 1}

Backfat thickness corrected for a uniform live body weight of $90 \mathrm{~kg}$ of and number of piglets born, born alive and weaned at different parities of Large White sows (Rückenspeckdicke korrigiert auf einheitliches Lebendgewicht von $90 \mathrm{~kg}$ und Anzahl der insgesamt geborenen, lebend geborenen und aufgezogenen Ferkel für die einzelnen Wurfnummern der Large-White-Sauen)

\begin{tabular}{cccccc}
\hline Parity & $\mathrm{n}$ & $\begin{array}{c}\text { backfat } \\
\text { thickness }\end{array}$ & piglets born & born alive & weaned piglets \\
\hline $1^{\text {st }}$ & 8285 & $10.99 \pm 1.85$ & $10.50 \pm 2.37$ & $9.81 \pm 2.22$ & $8.77 \pm 2.52$ \\
$2^{\text {nd }}$ & 5364 & $11.15 \pm 1.87$ & $11.23 \pm 2.48$ & $10.53 \pm 2.27$ & $9.42 \pm 2.62$ \\
$3^{\text {rd }}$ & 3526 & $11.26 \pm 1.89$ & $11.81 \pm 2.57$ & $10.95 \pm 2.32$ & $9.65 \pm 2.62$ \\
$4^{\text {th }}$ & 2246 & $11.48 \pm 1.86$ & $11.89 \pm 2.61$ & $10.98 \pm 2.32$ & $9.63 \pm 2.60$ \\
$5^{\text {th }}$ & 1377 & $11.67 \pm 1.89$ & $12.09 \pm 2.48$ & $11.05 \pm 2.20$ & $9.51 \pm 2.67$ \\
$6^{\text {th }}$ & 718 & $11.95 \pm 1.92$ & $11.93 \pm 2.72$ & $10.86 \pm 2.36$ & $9.05 \pm 3.09$ \\
$7^{\text {th }}$ and more & 322 & $12.21 \pm 2.21$ & $11.54 \pm 2.63$ & $10.45 \pm 2.30$ & $8.01 \pm 3.78$ \\
\hline
\end{tabular}

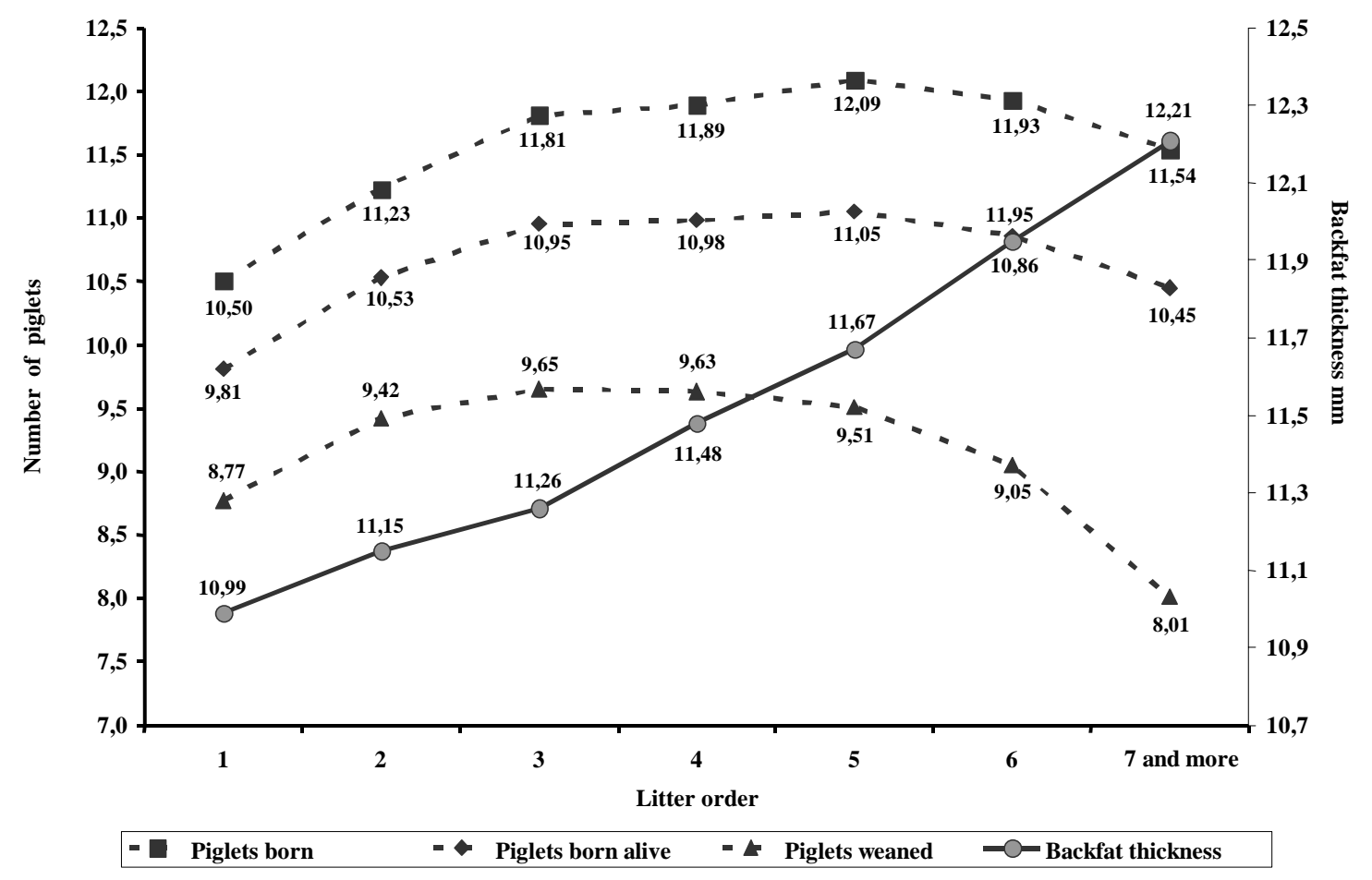

Figure: Number of total born piglets, born alive and weaned and the backfat thickness of sows on individual litters (Anzahl der insgesamt und lebend geborenen sowie der aufgezogenen Ferkel und die Rückenspeckdicke der Sauen innerhalb der einzelnen Wurfnummern) 
The statistical analysis revealed a highly significance $(\mathrm{P}<0.001)$ effect of litter number on fertility (Table 2). The backfat thickness did not show a significant effect on fertility; however, a certain tendency $(\mathrm{P}<0.096)$ was observed in case of the number of all piglets born.

Table 2

Results of variance analysis of piglet for litter size (Ergebnisse der Varianzanalyse für die Wurfgröße)

\begin{tabular}{lccc}
\hline Source of variability & piglets born & piglets born alive & piglets weaned \\
\hline Parity & $* * *$ & $* * *$ & $* * *$ \\
Backfat thickness & $0.096^{\mathrm{NS}}$ & $0.847^{\mathrm{NS}}$ & $0.507^{\mathrm{NS}}$ \\
\hline$* * * \mathrm{P}<0.001 ; \mathrm{NS}-$ non-significant & &
\end{tabular}

Coefficients of correlations existing between numbers of all, alive-born and weaned piglets on the one hand and the backfat thickness and litter rank of LW sows on the other are presented in Table 3. As one can see, the coefficients of correlation existing between the backfat thickness and fertility (expressed in numbers of all, alive-born and weaned piglets) are mostly negative and range closely around zero.

Table 3

Correlation coefficients of all, alive-born and weaned piglets on the one hand and backfat thickness on the other as dependent on the parity (Korrelation zwischen der Wurfgröße (Anzahl der insgesamt geborenen, lebend geborenen und aufgezogenen Ferkel) und der Rückenspeckdicke für die einzelnen Wurfnummern)

\begin{tabular}{lccccccc}
\hline Parity & $1^{\text {st }}$ & $2^{\text {nd }}$ & $3^{\text {rd }}$ & $4^{\text {th }}$ & $5^{\text {th }}$ & $6^{\text {th }}$ & $7^{\text {th }}$ \\
\hline Number of sows & 8,285 & 5,364 & 3,526 & 2,246 & 1,377 & 718 & 322 \\
Piglets born & $-0.2160^{*}$ & $-0.0380^{* *}$ & $-0.0307^{*}$ & -0.0249 & $-0.0717^{* *}$ & -0.0391 & $-0.0157^{*}$ \\
Born alive & $-0.0325^{* *}$ & $-0.3530^{* *}$ & $-0.0342^{*}$ & $-0.0474^{*}$ & $-0.0911^{* *}$ & -0.0034 & $-0.1227^{* *}$ \\
Piglets weaned & -0.0047 & -0.0057 & -0.0156 & -0.0482 & $-0.0530^{*}$ & -0.0195 & -0.0730 \\
\hline$* \mathrm{P}<0.05 ; * * \mathrm{P}<0.01$ & & & & & & &
\end{tabular}

\section{Discussion}

Numerous examinations deal with connection between back fat thickness and litter performances. HÜHN (1997) found that gilts with a fat thickness of 13-18 mm yielded higher farrowing rates and piglet numbers per 100 inseminated animals then the gilts with less fat thickness. KÄMMERER et al. (1998) observed that related to the results of all investigated gilts the deviations from total means were $\leq 13 \mathrm{~mm}$ side backfat thicknes $=-0.29$ respectively $\geq 18 \mathrm{~mm}=+0.18$ live born piglets. Similar conclusions found GUEBLEZ et al. (1985). KARSTEN et al. (2000) found genetic correlations between backfat thickness and total born piglets $\mathrm{f}_{\mathrm{g}}=0.18$ to 0.25 and WÄHNER et al. (2001a) observed significant correlations between side back fat thickness to number of born and alive born piglets just like the number of born piglets per 100 inseminated sows. Problems associated with the negative correlations existing between meateness and reproduction were studied by BRIEN (1986).

On the other hand VIDOVIC (1988), HEIDLER, HÜHN (1989) and GAUGHAM et al. (1995) found a very low phenotypic correlation between the back fat thickness and fertility parameters. Similar conclusions were drawn also by NELSON et al. (1990) and SUPERCHI et al. (1992). The reason of this results is the different age and weight of sows during fat thickness maesurements.

The results of this investigation indicate that sows with a thicker layer of backfat achieve better litter performance (Fig.) and more litter in the course of their lives. 
WHITTEMORE et al. (1995) mentioned that in primiparous sows an adequate layer of back fat assured their good performance anf fertility also after the $2^{\text {nd }}$ farrowing. A possible explanation is the hormon budget. So are GnRh and FSH key hormones for the endocrine regulation of follicular wave occurence. KANITZ et al. (2001) described the influence of estradiol-17ß to follicles mature for example and WÄHNER et al. (1995) observed that gilts with some more fat in their body have higher concentration of 17ß-estradiol in follicular fluid and in fat. Especially in prooestrus/oestrus a positive correlation is found between muscle-fat-relation and hormone concentration. Gilts with some more backfat show a higher ovarian activity with more follicles. The limit for muscle-fat-relation amount to 0.26 and gilts with some higher muscle-fat-relation have a better reproduction performance than gilts with a small fat portion in theit body. WÄHNER et al. (2001b) concluded that sows with a high predisposition for mobilisation of body fat realised the significant highest rearing performance.

In this investigation the increasing back fat thickness of sows with a higher number of parturitions indicate that a positive effect on the average longevity. The analysis of number of all, alive-born and weaned piglets again corroborated the fact that the fertility increased linearly. In spite of this, however, it is possible to say that back fat thickness was not too hight and that it can be cause of problems when involving gilts into the process of reproduction. The early time of measuring and comparatively low fat thickness in this field test can be cause that a statistically significant effect of back fat thickness on the number of piglets per litter was not demonstrated. This finding corresponds with conclusions published by WOLFOVA (1997). Similar conclusions were published by GAUGHAN et al. (1995) but he found also that young sows with the lowest thickness of back fat layer had a lower number of litters, the birth weight of piglets was lower and also the number of weaned piglets was reduced.

As far as the effect of parity on numbers of all born and alieve piglets were concerned, it can be notice that the $3^{\text {nd }}-5^{\text {nd }}$ parities are the best ones. This observation may be used when optimising the age structure of the breeding herd. In this investigation maximun numbers of all piglets were recorded in the $5^{\text {th }}$ parity, weaned piglets in the third parity. Similar results describe RASAJSKI (1990), WITTEMOORE et al. (1995), KISNER et al. (1995) and BÖSCH et al. (1999).

The results of this field test demonstrate sows with a thicker layer of back fat produced litters with a higher number of born alieve and weaned piglets, a positive effect on the average longevity and the maximum on fertility performances was rercorded increased od first to the $5^{\text {th }}$ parity.

\footnotetext{
References

BÖSH, M.; RÖHE, R.; LOOFT, H.; KALM, E.:

Selection for litter size in swine. Arch. Tierz., Dummerstorf 42 (1999) 6, 555 - 570 BRIEN, F. D.:

A review of the genetic and physiologica1 relationships between growth and reproduction in mammals. Anima1 Breeding Abstracts, 12, (1986), 975 - 997

ČECHOVÁ, M.; BUCHTA, S.:

Effect of genetic antagonism between reproductive and fattenig traits in pig dam breeds. Congress "Zěmědělství v marginálních podmínkách"; sborník referátů k 35. založení fakulty, ZF JU, České ČSN 41 6164: Budějovice, (1995), 291 - 297

Performance and progeny test in pigs.
} 
GAUGHAN, J. B.; CAMERON, R. D. A.; DRYDEN, G. MCL.; JOSEY, M. J.:

Effect of selection for leanness on overall reproductive performance in Large White sows. Animal Science, 61 (1995) 3, $561-564$

GUEBLEZ, R.; GESTIN, J. M.; HENAFF, G-LE.; LE-HENAFF, G.:

Effect of age and backfat thicknees at $100 \mathrm{~kg}$ on subsequent reproduction in Large White sows. 17emes Journees de 1a Recherche Porcine en France (1985), 113 - 112

HEIDLER, W.; HENNE, I.:

Die mit Ultraschall gemessenen Gewebsdicken von Sauen und deren Beziehungen zu ausgewählten Fruchtbarkeits- und Aufzuchtleistungen. Arch. Tierz., Berlin 32 (1989), 555-564

HÜHN, U.:

Zum Einfluss der Körperkondition von Jungsauen auf deren Erstabferkelleistungen nach biotechnischer Zyklussynchronisation. Arch. Tierz., Dummerstorf 40 (1997), 25-34

JOHN, A.; WÄHNER, M.; HOFFMEYER, C.:

Influence of growth and side fat thickness on reproduction and rearing performance of gilts. II. Relations between characteristics and discussion. Arch. Tierz., Dummerstorf 44 (2001) 3, 277 - 290

KÄMMERER, B.; MÜLLER, S.; HÜHN, U.:

Fruchtbarkeits- und Aufzuchtleistungen von Jungsauen mit unterschiedlicher Seitenspeckdicke zu Beginn der Zuchtbenutzung. Arch. Tierz., Dummerstorf 41 (1998) 4, 387-396

KANITZ, W.; BRÜSSOW, K.-P.; BECKER, F.; TORNER, H.; SCHNEIDER, F.; KUBELKA, M.; TOMEK, W.:

Comparative aspects of follicular development, follicular and oocyte maturation and ovulation in cattle and pigs. Arch. Tierz., Dummerstorf 44 (2001) Special Issue, 9-23

KARSTEN, S.; RÖHE, R.; SCHULZE, V.; LOOFT, H.; KALM, E.:

Genetische Beziehungen zwischen individueller Futteraufnahme während der Eigenleistungsprüfung und Fruchtbarkeitsmerkmalen beim Schwein. Arch. Tierz., Dummerstorf 43 (2000) 5, 451-451

KISNER,V.; MÖLLERS, B.; BRANDT, H.; GLODEK, P.:

Die Analyse von Sauenaufzuchtleistungen in der Versuchsstation Relliehausen zur Entwicklung von Kriterien der Wurfqualität. I. Mitt.: Der Einfluss der fixen Effekte der Rassenkombination, der Wurfnummer und die Verteilung der Geburtsgewichte. Arch. Tierz., Dummerstorf 38 (1995),73-86

LEMBER, A.:

Backfat Deposition and Utilization During the Reproductive Cycle of Gilts. Publishers of Tartu Agricultural University, (1994), 90 - 95

LUNDEHEIM, N.; ELIASSON-SELLING, L.:

Is culling due to a small first good business? Proceedings of the $14^{\text {th }}$ IPVS Congress, Bologna, Italy, (1996), 568

NELSON, A. E.; MABRY, J. W.; BYNESHEK, L. L.; MARKS, M. A.:

Correlated response in reproduction, growth and composition to selection in gilts for extremes in age at puberty and backfat. Livest. Prod. Sci., 24 (1990) 3, 237 - 247

NIBE, A.; SUGIMOTO, T.; TAKAHASHI, H.; ONOZATO, M.:

Analysis of field data on the effects of paraity and breed on the reproductive performance sows. Japanese J. of Swine Sci., 32 (1995) 1, 8 - 14

RASAJSKI, M.:

The investigation of sows fertility in connection with the age of boar and sow at fertilization. World Review of Anim. Prod., 25 (1990) 1, 23 - 28

SUPERCHI, P.; SABBIONI, A.; QUARANTELLI, A.; ZAVATTINI, S.:

Effects of fatness on reproductive efficiency of multiparous sows. Annali della Facolta di Medicina Veterinaria, Universita di Parma, 12 (1992), 133 - 142

ŠILER, R. et al.:

Growth in meat production in farm animals. SZN Praha, (1980), 276 pp.

TVRDOŇ, Z.; ČECHOVÁ, M.; DŘÍMALOVÁ, K:

Analysis of the impact of backfat thickness on fertility in sows. In: $18^{\text {th }}$ Genetic days, České Budějovice, (1998), 106

UNISTAT 4.53:

Unistat Statistical Software, Ltd., 4 Shirland Mens London, W9 3DY, United Kingdom, 1998

VIDOVIC, V.:

Genetic and phenotypic dependence reproduction in sows. Zbornik Radova, Institut za Stocarstvo, Novi Sad., 16 (1988), 115 - 123

WÄHNER, M.; ENGELHARDT, S.; SCHNURRBUSCH, U.; PFEIFFER, H.:

Beziehungen zwischen Kriterien des Fleisch- bzw. Fettansatzes und den 17ß-Ösradiol- bzw. Progesteronkonzentrationen in der Follikelflüssigkeit, im Muskel- und Fettgewebe, der Ovulationspotenz sowie der Fruchtbarkeitsleistung von Jungsauen. Arch. Tierz., Dummerstorf 38 (1995), 187-197 
WÄHNER, M.; JOHN, A.; HOFFMEYER, C.:

Zum Einfluss des Wachstums und der Seitenspeckdicke auf die Fruchtbarkeits- und Aufzuchtleistungen von Jungsauen. 1. Mitt.: Vergleich der Merkmale Wachstum, Seitenspeckdicke, Fruchtbarkeit und Aufzuchtleistungen. Arch. Tierz., Dummerstorf 44 (2001a) 2, 157-166

WÄHNER, M.; SCHOLZ, H.; KÄMMERER, B.:

Relationship between feed intake, side fat thickness and special parameters of rearing performance of lactating sows. Arch. Tierz., Dummerstorf 44 (2001b) 6, 639 - 648

WHITTEMOORE, C. T.; DOURMAD, J. Y.; ETTIENE, M.:

Reproduction in primiparous sows nutrition and body condition in relation to productivity. $46^{\text {th }}$ EAAP, Praha, (1995), 301

WOLFOVÁ, M.:

Are sows with higher backfat thickness kept longer in breeding? Náš chov, (1997) 5, 43

Received: 2005-08-15

Accepted: 2006-05-18

Author's addresses

Doc. Ing. MARIE ČECHOVÁ, CSc., Department of Animal Breeding, Faculty of Agronomy, Mendel University of Agriculture and Forestry Brno, Zemědělská 1

61300 BRNO, CZECH REPUBLIC

E-Mail: cechova@mendelu.cz

Ing. ZDENĚK TVRDOŇ, Ph. D.,

Genoservis, Co., J. Jabůrkové 1

77974 OLOMOUC, CZECH REPUBLIC

E-Mail: tvrdon2@seznam.cz 